\title{
Erratum to: JAK3-STAT pathway blocking benefits in experimental lupus nephritis
}

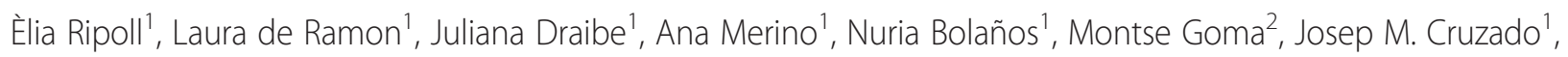
Josep M. Grinyó ${ }^{1}$ and Juan Torras ${ }^{1 *}$

Unfortunately, after publication of this article [1], it was noticed that the name of Juliana Draibe was listed incorrectly. The corrected name can be seen in the author list above and the original article has been updated to reflect this change.

\begin{abstract}
Author details
'Laboratori 4120. Nefrologia Experimental, 4a Planta Pavelló Govern, Universitat de Barcelona. Campus Bellvitge, Institut d'Investigació Biomèdica de Bellvitge (IDIBELL). Departament de Nefrologia, Hospital Universitari de Bellvitge, E-08907 L'Hospitalet, Barcelona, Spain. ²Departament d'Anatomia Patològica, Hospital Universitari de Bellvitge, E-08907 L'Hospitalet, Barcelona, Spain.
\end{abstract}

Received: 21 June 2016 Accepted: 22 June 2016

Published online: 01 July 2016

\section{Reference}

1. Ripoll Ė, de Laura R, Draibe J, Merino A, Bolaños N, Goma M, Cruzado JM, Grinyó JM, Torras J. JAK3-STAT pathway blocking benefits in experimental lupus nephritis. Arthr Res Ther. 2016;18:134. doi:10.1186/s13075-016-1034-x.

* Correspondence: 15268jta@comb.cat

'Laboratori 4120. Nefrologia Experimental, 4a Planta Pavelló Govern, Universitat de Barcelona. Campus Bellvitge, Institut d'Investigació Biomèdica de Bellvitge (IDIBELL). Departament de Nefrologia, Hospital Universitari de Bellvitge, E-08907 L'Hospitalet, Barcelona, Spain

\footnotetext{
Submit your next manuscript to BioMed Central and we will help you at every step:

- We accept pre-submission inquiries

- Our selector tool helps you to find the most relevant journal

- We provide round the clock customer support

- Convenient online submission

- Thorough peer review

- Inclusion in PubMed and all major indexing services

- Maximum visibility for your research
}

Submit your manuscript at www.biomedcentral.com/submit (c) 2016 The Author(s). Open Access This article is distributed under the terms of the Creative Commons Attribution 4.0 International License (http://creativecommons.org/licenses/by/4.0/), which permits unrestricted use, distribution, and reproduction in any medium, provided you give appropriate credit to the original author(s) and the source, provide a link to the Creative Commons license, and indicate if changes were made. The Creative Commons Public Domain Dedication waiver (http://creativecommons.org/publicdomain/zero/1.0/) applies to the data made available in this article, unless otherwise stated. 